\title{
An empirical assessment of the SERVQUAL scale
}

\begin{abstract}
Mahla Zargar*
Department of Business and Management, Iran University of Science and Technology, Tehran, Iran

\begin{tabular}{l}
\hline C H R O N I C L E \\
\hline Article history: \\
Received June 5, 2015 \\
Received in revised format \\
August 162015 \\
Accepted January 22015 \\
Available online \\
January 42016 \\
\hline Keywords: \\
SERVQUAL \\
Point of sales \\
Quality \\
\end{tabular}

During the past few years, many people have used point of sales for purchasing goods and services. Point of sales tends to provide a reliable method for making purchases in stores. Implementation of point of sales may reduce depreciation cost of automated telling machines and helps banks increase their productivities. Therefore, for bank managers, it is important to provide high quality services. This paper presents an empirical investigation to measure quality service using SERVQUAL scale. The study first extracts six factors including Trust, Responsiveness, Reliability, Empathy, Tangibles and getting insight for future development through the implementation of structural equation modeling. Next, it has implemented structural equation modeling and realizes that all components had positive impacts on customer satisfaction.
\end{abstract}

\section{Introduction}

During the past several years, many people have been using point of sales for purchasing goods and services. Point of sales tends to provide a reliable method for making purchases in stores (CarboValverde \& Rodriguez-Fernandez, 2008). Implementation of point of sales may reduce depreciation cost of automated telling machines and helps banks increase their productivities. Therefore, for bank managers, it is important to provide high quality services. Farokhi et al. (2016) implemented the information gathered from point of sales in one of Iranian private banks and using two methods of KMeans and Kohonen, customers were clustered into four segments to detect the most profitable customers. Two Step Cluster is a technique for analyzing large datasets and the algorithm groups the observations in clusters, based on the approach criterion according to an agglomerative hierarchical clustering method (Şchiopu, 2010). Arasli et al. (2005) measured the service quality perceptions of Greek Cypriot bank customers by examining the relationship between service quality, customer satisfaction and positive word of mouth (WOM), in the presence of changing bank market dynamics. Using SERVQUAL method (Parasuraman et al., 1985, Asubonteng et al., 1996), the study disclosed

* Corresponding author.

E-mail address: mahla.zargar806@gmail.com (M. Zargar) 
that bank customers could not reach their expectations where the largest gap was gained in the responsiveness-empathy dimension. In their study, reliability items maintained the highest effect on customer satisfaction, which kept a statistically significant impact on the positive WOM. Parasuraman et al. (2005) conceptualized, constructed, refined, and examined a multiple-item scale (E-S-QUAL) for studying the service quality given by Web sites in which customers shop online. In their survey, a twostage data collection disclosed that two different scales were important for capturing electronic service quality.

\section{The proposed study}

This paper presents an empirical investigation to study the impacts of service quality on point of sales. The study uses a questionnaire for measuring service quality, which is adapted from Parasuraman's work (Parasuraman et al., 1985, 2005). The study has accomplished among regular users of point of sales who live in city of Tehran, Iran during the year of 2015. The sample size is calculated as follows,

$$
N=Z_{\alpha / 2}^{2} \frac{p \times q}{e^{2}}
$$

where $N$ is the sample size, $p=1-q$ represents the probability, $z_{\alpha / 2}$ is CDF of normal distribution and finally $\varepsilon$ is the error term. For our study we assume $p=0.5, z_{\alpha / 2}=1.96$ and $e=0.05$, the number of sample size is calculated as $N=384$. The survey has distributed 400 questionnaires and managed to collect 400 properly filled ones. The questionnaire of the survey consists of 23 questions on service quality including Trust, Responsiveness, Reliability, Empathy, Tangibles and getting insight for future development. Cronbach alphas for these components are 0.917, 0.901, 0.846, 0.835, 0.824 and 0.795, respectivley. The study uses principle component analysis to extract effective factors influencing on quality of services. Cronbach alpha is calculated as 0.895 and Kaiser-Meyer-Olki Measure of Sampling Adequacy (KMO) test is summarized in Table 1 as follows,

Table 1

The results of KMO test

\begin{tabular}{|c|c|c|}
\hline Kaiser-Meyer-O & Sampling Adequacy & 0.895 \\
\hline \multirow{3}{*}{ Bartlett's Test of Sphericity } & Approx. Chi-square & $3.282 \mathrm{E} 3$ \\
\hline & Df & 253 \\
\hline & Sig & .000 \\
\hline
\end{tabular}

As we can observe from the results of Table 1, the questionnaire provides acceptable results and can be further analyzed. The implementation of principle component analysis has yielded six factors. Fig. 2 shows the results of Scree plot.

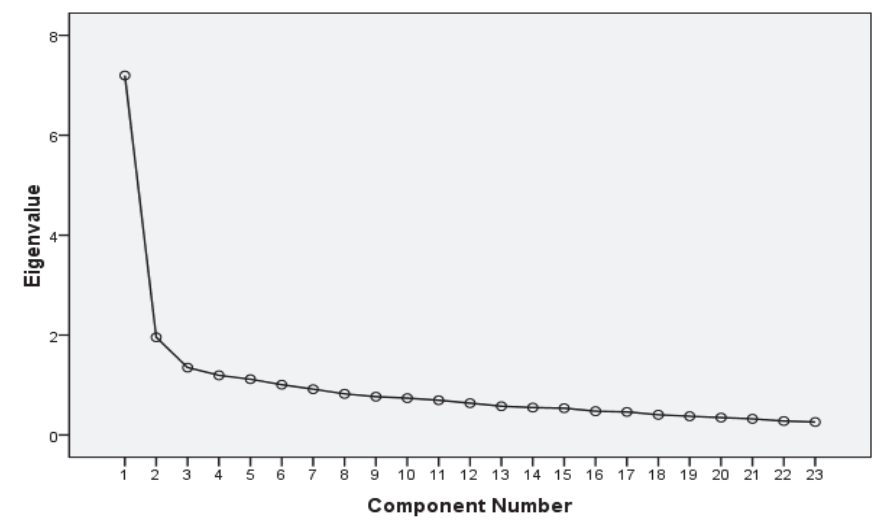

Fig. 2. The results of Scree plot 
In addition, Table 2 presents the results of PCA after Varimax rotation. Fig. 3 shows the results of structural equation modeling on testing the effects of these six components.

\section{Table 2}

The summary of PCA after rotation

\begin{tabular}{|c|c|c|c|c|c|c|}
\hline \multicolumn{7}{|c|}{ Components } \\
\hline & 1 & 2 & 3 & 4 & 5 & 6 \\
\hline VAR00001 & .225 & .119 & -.095 & -.080 & .175 & .715 \\
\hline VAR00002 & -.093 & .110 & .235 & .231 & .081 & .677 \\
\hline VAR00003 & .253 & .184 & .243 & -.040 & .144 & .413 \\
\hline VAR00004 & .423 & .021 & .084 & .133 & .101 & .446 \\
\hline VAR00005 & .767 & .206 & .082 & .045 & .202 & .185 \\
\hline VAR00006 & .748 & .144 & .174 & .117 & .175 & .067 \\
\hline VAR00007 & .522 & .069 & .532 & .071 & .051 & -.035 \\
\hline VAR00008 & .615 & .230 & .372 & .041 & .144 & .155 \\
\hline VAR00009 & .333 & .159 & .686 & .008 & .094 & .106 \\
\hline VAR00010 & .222 & .784 & .147 & .140 & -.002 & .119 \\
\hline VAR00011 & .233 & .838 & .013 & .150 & .037 & .055 \\
\hline VAR00012 & .290 & .344 & .025 & .122 & .577 & -.090 \\
\hline VAR00013 & .296 & .003 & .146 & -.006 & .561 & .039 \\
\hline VAR00014 & .035 & .015 & .175 & .092 & .735 & .176 \\
\hline VAR00015 & .064 & .081 & .087 & .065 & .592 & .335 \\
\hline VAR00016 & -.023 & .607 & .316 & .145 & .199 & .212 \\
\hline VAR00017 & .125 & .483 & .351 & .234 & .298 & .138 \\
\hline VAR00018 & .048 & .120 & .818 & .060 & .166 & .089 \\
\hline VAR00019 & .388 & .196 & .507 & .091 & .297 & .173 \\
\hline VAR00020 & .366 & .334 & .395 & .224 & .370 & .151 \\
\hline VAR00021 & .140 & .146 & .039 & .804 & .010 & .134 \\
\hline VAR00022 & .007 & .162 & .078 & .739 & .186 & -.067 \\
\hline VAR00023 & .077 & .102 & .036 & .839 & .023 & .081 \\
\hline
\end{tabular}

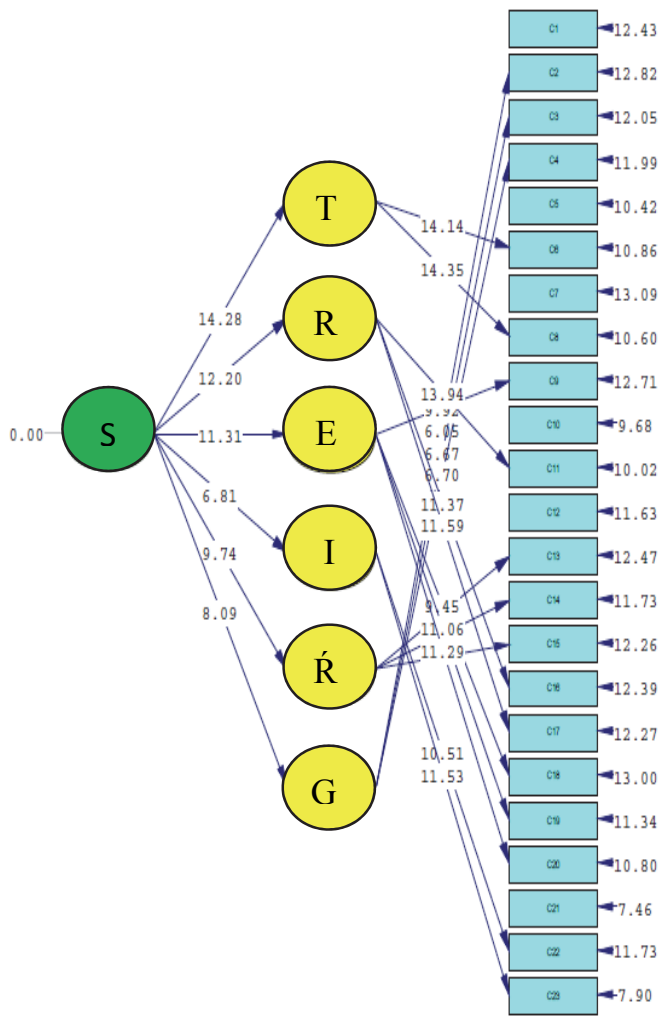

S: Customer satisfaction, T: Trust, R: Responsiveness, E: Empathy, I: Getting insight for future development, R: Reliability, G: Tangible Chi-Square $=596.66(0.00000) \mathrm{df}=17.25 \mathrm{CFI}=0.98, \mathrm{CFI}=0.98, \mathrm{NNFI}=0.97, \mathrm{NFI}=0.99, \mathrm{GFI}=0.99, \mathrm{AGFI}=0.95, \mathrm{RMSEA}=0.064$

Fig. 2. The results of t-values of the structural equation modeling on the effects of six variables on customer satisfaction 
Fig. 2 also presents the results of statistics associated with the implementation of structural equation modeling. As we can can observe, all statistics are within desirable level and we can examine the effects of six components on customer satisfaction. Finally, Table 3 summarizes the results of our survey.

\section{Table 3}

The summary of testing the effects of various factors on customer satisfaction

\begin{tabular}{lcccc}
\hline & Mean & Standard deviation & t-value & Result \\
\hline Reliability & 5.92 & 1.02 & 14.28 & Confirmed \\
Responsiveness & 6.64 & 1.09 & 12.20 & Confirmed \\
Empathy & 5.93 & 1.07 & 11.31 & Confirmed \\
Trust & 6.91 & 0.84 & 9.74 & Confirmed \\
Tangible & 7.34 & 1.135 & 8.09 & Confirmed \\
Getting insight for future development & 7.46 & 0.79 & 6.81 & Confirmed \\
\hline
\end{tabular}

\section{Conclusion}

The recent advances on technology has created tremendous opportunity to facilitate financial transaction. People now are able to transfer funds, purchase products or services using electronic equipment. In this paper, we have presented an empirical investigation to study the effects of different factors on customer satisfaction who use point of sales services. The results of our survey have indicated that all six components extracted through the implementation of principle component analysis have positively influenced on customer satisfaction.

\section{Acknowledgement}

The authors would like to thank the annonymous referees for constructive comments on earlier version of this paper.

\section{References}

Arasli, H., Mehtap-Smadi, S., \& Katircioglu, S. T. (2005). Customer service quality in the Greek Cypriot banking industry. Managing Service Quality, 15(1), 41-56.

Asubonteng, P., McCleary, K. J., \& Swan, J. E. (1996). SERVQUAL revisited: a critical review of service quality. Journal of Services marketing,10(6), 62-81.

Carbo-Valverde, S., \& Rodriguez-Fernandez, F. (2008, November). ATMs vs. POS Terminals: A Horse Race?. In 21st Australasian Finance and Banking Conference.

Farokhi, S., Teimourpour, B., Shekarriz, F \& Masoudi, M. (2016). A new application of clustering for segmentation of banks' e-payment services based on profitability. Uncertain Supply Chain Management, 4(1), 55-60.

Parasuraman, A., Zeithaml, V. A., \& Berry, L. L. (1988). Servqual. Journal of retailing, 64(1), 12-37.

Parasuraman, A., Zeithaml, V. A., \& Malhotra, A. (2005). ES-QUAL a multiple-item scale for assessing electronic service quality. Journal of service research, 7(3), 213-233.

Şchiopu, D. (2010). Applying TwoStep cluster analysis for identifying bank customers' profile. Buletinul, 62, 66-75. 